\title{
EVALUASI OOSIT KAMBING HASIL IVM SEBAGAI SALAH SATU FAKTOR PENENTU KEBERHASILAN DALAM AKTIVASI PARTENOGENESIS
}

\author{
Kholifah Holil \\ Jurusan Biologi, Fakultas Sains dan Teknologi \\ Universitas Islam Negeri (UIN) Maulana Malik Ibrahim Malang \\ Email: ifa_biomolrep03@yahoo.com
}

\begin{abstract}
Abstrak
Aktivasi partenogenesis merupakan salah satu tehnik aktivasi oosit untuk menghasilkan embrio tanpa kontribusi dari sperma. Salah satu faktor yang menentukan keberhasilan tehnik ini adalah pada ketersediaan oosit yang berkualitas. Oleh karena itu penelitian ini bertujuan untuk mengevaluasi oosit kambing hasil IVM yang dapat digunakan untuk kepentingan dalam aktivasi partenogenesis tersebut.

Sampel yang digunakan dalam penelitian ini adalah oosit yang diaspirasi dari folikel ovarium kambing yang diambil dari RPH Sukun Malang. Oosit di IVM selama 24 jam dan selama 27 jam dalam medium TCM-199 yang ditambah dengan fetal bovine serum (FBS), follicle-stimulating hormone (FSH) dan lutheinizing hormone ( $L H)$ dan diinkubasi pada suhu $38,5^{\circ} \mathrm{C}, 5 \% \mathrm{CO}_{2}$. Pada jam ke 24 dan jam ke 27 setelah IVM dilakukan pengamatan yang meliputi ekspansi sel-sel kumulus dan keberadaan polar body I (PB-I) pada jam ke 30.

Berdasarkan hasil penelitian menunjukkan bahwa oosit kambing yang di IVM sampai jam ke 24 belum menunjukkan adanya ekspansi sel-sel kumulus kualitas 2 dan penampakan PB-I. Hasil tersebut berbeda dengan oosit yang di IVM sampai jam ke 27. Pada pengamatan jam ke 27 ini menunjukkan bahwa terdapat 77,87\% oosit yang sel-sel kumulusnya berekspansi (kualitas 2) dan PB-I yang nampak sebesar 95,32\%. Dengan demikian maka dapat disimpulkan bahwa oosit kambing hasil IVM baru dapat digunakan untuk keperluan lebih lanjut khususnya untuk keperluan aktivasi partenogenesis pada jam ke 27.
\end{abstract}

Kata kunci: evaluasi, aktivasi partenogenesis, oosit kambing hasil IVM

\section{PENDAHULUAN}

Hafez (2000) mengemukakan bahwa oosit secara umum dalam kehidupannya mengalami 2 periode yaitu periode pertumbuhan (period of growth) dan periode pematangan (period of maturation). Pada periode pertumbuhan oosit tumbuh sempurna pada saat berada pada waktu pembentukan antrum sampai pada saat pembentukan cumulus oophorus sudah dalam kondisi kuat. Sedangkan periode pematangan terjadi pada saat meiosis yaitu pada saat fetal ovary dan pada saat sebelum lahir (tahap diploten) yang kemudian terhenti dan berlanjut kembali sampai oosit siap untuk melakukan fertilisasi. Pada kondisi ini oosit ada dalam fase metafase II (MII).

Dalam periode pematangan, oosit mengalami 2 hal yaitu maturasi inti (nuclear maturation) dan maturasi sitoplasma (cytoplasmic maturation). Pada maturasi inti, oosit mengalami berbagai proses yaitu dimulai dari proses munculnya germinal vesicle break down (GVBD), kondensasi kromosom, proses pembentukan spindel pada metafase I, proses pemisahan kromosom homolog dengan ekstruksi polar body II sampai pada saat MII (Kubelka et al., 1995).

Sedangkan maturasi sitoplasma menyangkut perubahan morfologi dan ultrastruktur dari organel-organel penyusun oosit. Kruip et al., (1983) dalam Mayes, (2002) mengemukakan bahwa terjadinya perubahan morfologi dan ultrastruktur pada maturasi sitoplasma secara tidak langsung menyangkut kemampuan dalam hal untuk bisa berfertilisasi secara normal, cleavage dan berkembang menjadi blastosis (Kruip et al., 1983 dalam Mayes, 2002).

Contoh penting terjadinya perubahan ultrastruktur selama maturasi oosit tersebut dapat dilihat pada keberadaan sel-sel kumulus sebagai pemberi makan bagi oosit dan sebagai penyedia produk kunci developmental competence. Kadar glutathion rendah pada oosit immature dan meningkat selama maturasi dan turun pada tahap awal perkembangan embrio. Perreault et al., (1988) dalam Mayes, 
(2002) mengemukakan bahwa glutathion terlibat dalam reduksi ikatan disulfide pada dekondensasi kromatin sperma dan penggantian protamin oleh histon. Kehadiran dan ketidakhadiran sel-sel kumulus berperan bagi oosit untuk dapat berkembang lebih lanjut. Zhang et al., (1995) dalam Mayes (2002) mengemukakan bahwa oosit gundul yang dikultur secara in vitro akan mampu mencapai MII tetapi tidak mampu untuk berkembang lebih lanjut.

Partenogenesis adalah proses produksi embrio tanpa melalui proses fertilisasi yaitu tanpa peran dari gamet jantan (Rougier, 2001). Dalam proses ini dibutuhkan oosit dengan kualitas yang bagus yaitu oosit yang ada dalam kondisi MII. Salah satu jalur yang bisa ditempuh untuk dapat melakukan proses partenogenesis ini adalah melalui jalur in vitro yaitu dengan cara mematurasi oosit immature dengan menggunakan medium tertentu sehingga didapatkan oosit yang mature. Pada oosit mature maka oosit akan ada dalam MII dan siap untuk diaktivasi untuk menghasilkan embrio melalui partenogenesis.

Evaluasi kualitas oosit hasil IVM menjadi langkah penting yang harus dilakukan untuk dapat menyediakan oosit yang ada dalam MII. Kondisi oosit yang belum mature akan menjadi satu faktor ketidakberhasilan dalam aktivasi partenogenesis. Ini dimungkinkan karena hanya oosit yang ada dalam keadaan MII sajalah yang hanya bisa melanjutkan pada proses pembelahan berikutnya untuk selanjutnya menghasilkan embrio partenot.

\section{BAHAN DAN METODE Bahan}

Bahan yang digunakan dalam penelitian ini adalah oosit kambing immature yang diperoleh dengan cara mengaspirasi folikel ovarium kambing yang diambil dari RPH Sukun Malang, TCM 199 (Gibco-BRL), $\mathrm{NaHCO}_{3}$ (Merck), HEPES (USB, Ohio), FBS (Gibco-BRL), penicillin (Meiji Seika, Tokyo), streptomycin (Meiji Seika, Tokyo), $\mathrm{NaCl}$ Fisiologis 0,9\% (Merck), etanol (Merck), cycloheximide (Sigma chemical), 6-DMAP (Sigma chemical), paraffin oil (Merck), enzim hyaluronidase (Sigma chemical), FSH, LH, dan parafilm.

Alat yang digunakan dalam penelitian ini adalah falcon (Iwaki, ukuran $35 \mathrm{~mm}$ ), disposable syringe $10 \mathrm{ml}$ dengan jarum ukuran 21Gx11/2", petri dish, blue tip, yellow tip, rak tabung dan tabung reaksi, bunsen, millipore, hematokrit (Assistent), mikroskop elektron, autoklaf, oven, dan incubator $\mathrm{CO}_{2}$.

\section{Metode}

Metode in vitro maturation (IVM) yang digunakan dalam penelitian ini adalah metode yang didasarkan pada metode Gordon (1994) yang telah mengalami modifikasi dan terdiri dari beberapa tahap yaitu tahap koleksi ovarium dari RPH, aspirasi oosit, washing oosit, seleksi oosit dan maturasi oosit .

Koleksi ovarium dari RPH: Ovarium yang diperoleh dari hasil pemotongan hewan dimasukkan ke dalam $0,9 \% \mathrm{NaCl}$ fisiologis yang telah ditambah dengan antibiotik (Streptomicyn+Penicillin), dibersihkan dari jaringan lemak yang melekat dan kemudian dimasukkan kembali ke dalam 0,9\% $\mathrm{NaCl}$ fisiologis yang lain, ditutup rapat dan dibawa ke laboratorium.

Aspirasi oosit: Ovarium hasil koleksi dari RPH di dalam laboratorium dimasukkan ke dalam waterbath pada suhu $38^{\circ} \mathrm{C}$, dan selanjutnya dalam kondisi steril maka oosit diaspirasi melalui folikel antral yang berdiameter $3-7 \mathrm{~mm}$ dengan menggunakan disposable syringe $10 \mathrm{ml}$ dan jarum berukuran $21 \mathrm{G}$ (spuit diisi dengan 0,5-1ml washing medium). Hasil aspirasi kemudian ditempatkan dalam tabung reaksi yang berada dalam waterbath yang sama.

Washing oosit: hasil aspirasi dalam tabung reaksi diendapkan selama 10 menit, dibuang bagian atasnya, ditambah dengan washing medium, dan hal yang sama dilakukan sebanyak 3x. Selanjutnya pada pengendapan yang terakhir maka hasil yang didapat dituangkan ke dalam petri dish kecil dan siap untuk diamati dan diseleksi di bawah mikroskop.

Seleksi oosit: oosit diseleksi di bawah mikroskop inverted dengan cara dipilih hanya oosit dengan cumulus oophorus dan corona radiata yang kompak.

Maturasi oosit: dengan menggunakan hematokrit maka oosit yang sudah diseleksi dipindahkan ke dalam medium maturasi yang telah diinkubasi minimal 2 jam sebelum digunakan dan kemudian diinkubasi dalam inkubator yang berkadar $\mathrm{CO}_{2} 5 \%$, suhu $38,5^{\circ} \mathrm{C}$ selama $1 \times 24$ jam. Tahap pemindahan oosit dalam IVM tersaji pada gambar 5 di bawah ini. 


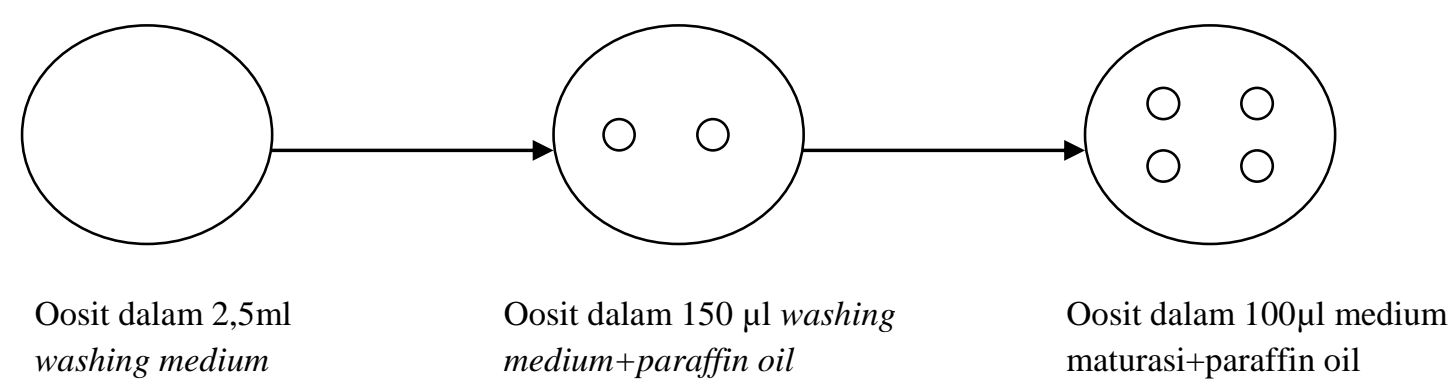

Gambar 1. Tahap pemindahan oosit dalam IVM

Evaluasi oosit: Pada jam ke-24 dan jam ke 27 IVM oosit yang telah dimaturasi diamati perkembangan sel-sel kumulusnya dan pada jam ke-30 IVM diamati keberadaan first polar body yang dimilikinya. Perkembangan sel-sel kumulus dikelompokkan menjadi 3 yaitu kualitas 0 (oosit dengan sel-sel kumulus yang tidak berkembang sama sekali), kualitas 1 (oosit dengan sel-sel kumulus yang berkembang hanya sebagian), dan kualitas 2 (oosit dengan sel-sel kumulus yang berkembang seluruhnya). Sedangkan keberadaan first polar body dapat diamati setelah sel-sel sel-sel kumulus yang mengelilingi oosit dihilangkan dengan cara diinkubasi dalam $0,1 \%$ enzim hyaluronidase selama 5 menit diikuti dengan pipetting pada suhu ruang. Lebih lanjut maka hanya oosit dengan first polar body dan sel-sel kumulus dengan kualitas 2 saja yang dimaturasi kembali sampai jam ke-30 IVM.

\section{HASIL PENELITIAN DAN PEMBAHASAN}

Salah satu faktor yang menunjang keberhasilan aktivasi partenogenesis adalah kualitas oosit yang digunakan harus ada dalam kondisi mature. Untuk mendapatkan oosit yang mature ini maka perlu dilakukan IVM dengan menggunakan oosit immature. Pada kondisi ini, oosit akan mampu untuk menyelesaikan meiosis I dan berkembang sampai pada tahap MII (Moussa, 1998). Smith (2001) mengemukakan bahwa keberhasilan IVM dapat dievaluasi ketika oosit mampu menyelesaikan maturasi inti, mampu melakukan fertilisasi dan mampu berkembang menjadi embrio. Sedangkan secara morfologi salah satu indikator bahwa oosit ada dalam kondisi mature adalah kenampakan adanya polar body I (PB-I).

Berdasarkan hasil penelitian yang telah dilakukan menunjukkan bahwa oosit immature yang dimaturasi secara in vitro yang diamati pada jam ke 24 IVM belum memperlihatkan ekspansi sel-sel kumulus kualitas 2 (data tidak ditunjukkan). Akan tetapi ekspansi sel-sel kumulus terlihat pada jam ke 27 IVM dan PB-I baru terlihat pada jam ke 30 IVM. Berikut ini adalah evaluasi hasil IVM yang diamati pada jam ke-27 (ekspansi sel-sel kumulus) dan jam ke-30 (kenampakan PB-I).

Tabel 1. Evaluasi hasil IVM ekspansi sel-sel kumulus kualitas 2 (jam ke-27 IVM) dan kenampakan PB-I (jam ke-30 IVM)

\begin{tabular}{clcc}
\hline No & \multicolumn{1}{c}{ Parameter } & $\begin{array}{c}\text { Total } \\
\text { oosit } \\
(\mathbf{N})\end{array}$ & Persentase \\
\hline 1 & Oosit yang di IVM & 357 & - \\
\hline 2 & $\begin{array}{l}\text { Ekspansi sel-sel } \\
\text { kumulus kualitas 2 }\end{array}$ & 278 & 77,87 \\
\hline 3 & Kenampakan PB-I & 265 & 95,32 \\
\hline
\end{tabular}

Dari Tabel 1 di atas terlihat bahwa dari 357 oosit yang dimaturasi maka hanya 278 oosit yang mampu berkembang lebih lanjut (kualitas 2) atau hanya 77,87\%. Kualitas 2 ini dicirikan dengan terjadinya ekspansi seluruh sel-sel kumulus yang mengelilingi oosit (Gambar 2). Sedangkan PB-I yang nampak hanya sebesar 95,32\%. Ini artinya dari 278 oosit kualitas 1 setelah digunduli pada jam ke-27 IVM hanya ada 265 oosit yang menampakkan adanya PB-I (Gambar 2). Tidak nampaknya PB-I pada semua oosit yang dimaturasi bukan berarti oosit tidak mature. Suss dan Madison (1983) dalam Gordon (1994) mengemukakan bahwa dari beberapa oosit yang dimaturasi kirakira sekitar $50 \%$ diantaranya menunjukkan adanya PB dengan konfigurasi kromosom pada MII. 

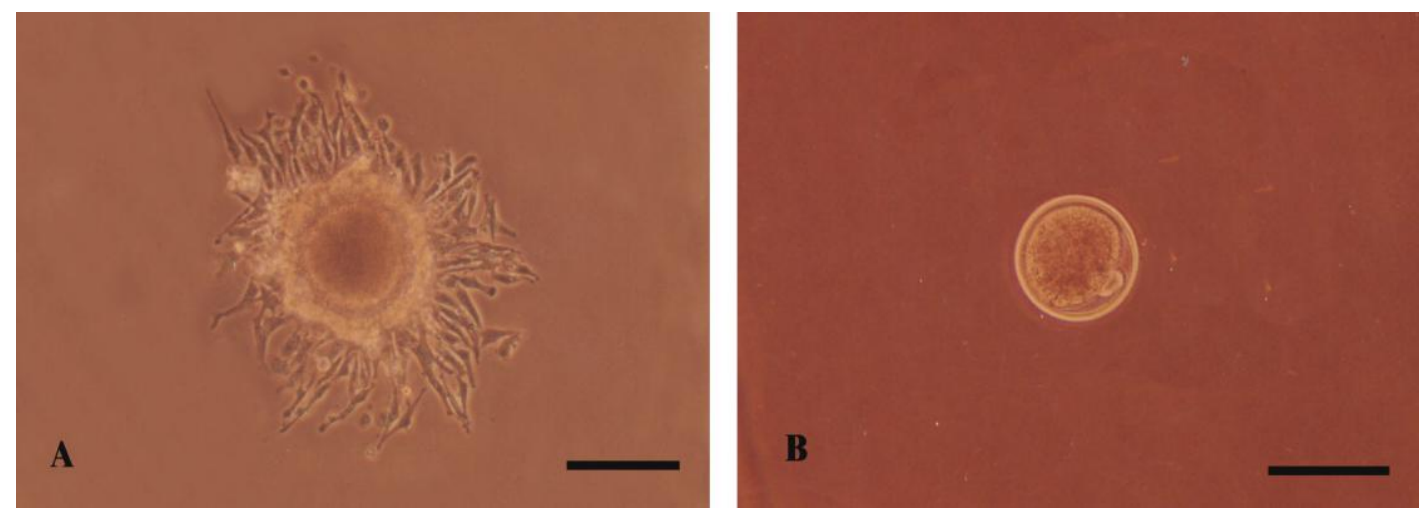

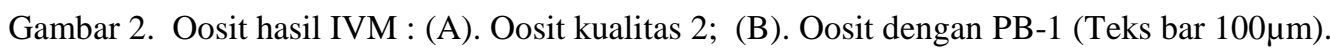

Oosit yang ada dalam MII tersebut baru bisa menyelesaikan meiosis jika mengalami fertilisasi. Nurse (1990) mengemukakan bahwa MII pada oosit terjadi karena tingginya aktivitas Maturing Promoting Factor (MPF) yang merupakan protein kompleks yang tersusun atas 2 subunit yaitu p34 ${ }^{\text {cdc2 }}$ dan cyclin B. Aktivasi MPF diinduksi oleh cyclin B yang dalam proses ini memerlukan fosforilasi threonin dan defosforilasi tirosin pada $\mathrm{p} 34^{\text {cdc2 }}$.

Murray dan Kirschner (1989) mengemukakan bahwa pada sel-sel eukariotik, aktifitas kinase yang ada pada MPF mampu menginisiasi terjadinya sejumlah reaksi yang menghasilkan nuclear envelope breakdown (NEBD), kondensasi kromosom dan pembentukan spindel metafase (assembly of the metaphase spindle). Berbagai penelitian yang ada menyebutkan bahwa kadar MPF relatif rendah pada tahap germinal vesicle dan terus menerus meningkat seiring dengan perkembangan meiosis sampai pada tahap metafase I (Grupen et al., 2002) selanjutnya menurun pada saat sel masuk fase anafase I dan fase telofase I tetapi meningkat kembali pada saat sel masuk dalam fase metafase II sebagaimana halnya seperti yang dialami pada saat metafase I. Sementara itu, cyclin B disintesa dan terakumulasi ketika p34 $4^{\text {cdc2 }}$ ada dalam sitoplasma yaitu pada saat interfase (Solomon et al., 1990 dalam Mayes, 2002) dan terdegradasi oleh ubiquitin-dependent proteolysis. Sebaliknya kadar $\mathrm{p} 34^{\mathrm{cdc} 2}$ tidak berubah selama meiosis (Choi et al., 1991).

Pada oosit MII, perubahan kadar MPF bergantung pada keberadaan cytostatic factor (CSF) yaitu suatu protein kompleks yang tersusun atas beberapa macam protein seperti $c$ mos proto-oncogen, cyclin-dependent kinase 2 (cdk2), mitogen-activated protein kinase (MAPK) dan p90 ${ }^{\text {Rsk }}$ (Nurse, 1990). CSF berfungsi untuk mencegah degradasi cyclin $\mathrm{B}$ agar MPF tetap aktif. Ketika CSF inaktif maka yang terjadi adalah degradasi cyclin B dan ini menyebabkan MPF juga inaktif sehingga meiosis berlanjut kembali. Lorca et al., (1993) mengemukakan bahwa inaktivasi CSF terjadi karena peran calmodulin-dependent protein kinase (CaMKII) melalui penyediaan kalsium intraselluler yang cukup dalam signal transduction pathway.

\section{KESIMPULAN DAN SARAN}

Berdasarkan hasil penelitian yang dilakukan maka dapat disimpulkan bahwa oosit hasil IVM pada jam ke 27 siap untuk digunakan untuk keperluan selanjutnya dalam aktivasi partenogenesis. Ini ditunjukkan dengan $77,87 \%$ oosit yang di IVM memperlihatkan ekspansi sel-sel kumulus kualitas 2 dan penampakan adanya PB-I sebesar 95,32\%. Namun demikian, hasil penelitian ini berupa oosit matur yang ada dalam MII perlu diuji lebih lanjut keberadaan protein yang berperan dalam proses maturasi tersebut dan juga perlu digunakan tidak hanya untuk keperluan aktivasi partenogenesis akan tetapi juga untuk keperluan lain dalam teknologi reproduksi seperti IVF, kloning dan lain-lain.

\section{DAFTAR PUSTAKA}

Choi T., Aoki F., Mori M., Yamashita M., Nagahama Y., dan Kohmoto K. 1991. Activation of $\mathrm{p} 34 \mathrm{cdc} 2$ protein kinase activity in meiotic and mitotic cell cycles in mouse oocytes and embryos. Abstracts Development. 113 (3):789-95. 
Gordon I. 1994. Laboratory production of cattle embryos. Cab Internasional. Cambridge.

Grupen CG., Nottle MB., dan Nagashima H. 2002. Calcium release at fertilization: artificially mimicking the oocyte's response to sperm.Reproduction and Development. 48(4): 313-333.

Hafez. 2000. Reproduction in farm animal. Seventh edition. Lippincot Williams and Wilkin. New York.

Kubelka M., Rimkevicova Z., Guerrier P., dan Motlik J. 1995. Inhibition of protein synthesis affects histone H1 kinase, but not chromosome condensation activity, during the first meiotic division of pig oocytes. Abstracts Mol Reprod Dev. 41(1): 63-69.

Lorca T., Cruzalegui FH., Fesquet D., Cavadore JC., Mery J., Means A., dan Doree M. 1993. Calmodulint-dependent protein kinase II mediates inactivation of MPF and CSF upon fertilization of Xenopus eggs. Abtracs Nature. 366: 270-273.

Moussa AA. 1998. IVM of oocytes. www.obgyn.net. January, 6, 2005.

Murray AW., dan Kirschner MW. 1989. Cyclin synthesis drives the early embryonic cel cycle. Nature. 339: 275-280.

Nurse P. 1990. Universal control mechanism regulating onset of M-phase. Abstracts Nature. 344: 503-508.

Rougier N., dan Werb Z. 2001. Parthenogenesis in mammals. Molecular Reproduction and Development. 59: 468-474.

Smith GD. 2001. In vitro maturation of oocytes. www.biomedcentral.com. August, 6, 2004. 